\title{
Pharmacognosy Optimization of phenolic compounds extraction from Campomanesia lineatifolia leaves
}

\author{
Nivea Cristina Vieira Neves ${ }^{1,2,3,4}$, Morgana Pinheiro de Mello ${ }^{1}$, Juliana Mendes Amorim ${ }^{1}$, \\ André Augusto Gomes Faraco ${ }^{1} \&$ Rachel Oliveira Castilho ${ }^{1}$
}

\begin{abstract}
Campomanesia lineatifolia (gabiroba) is a native edible species found in the Amazon Rainforest. Previous studies have demonstrated the flavonoid nature of ethanolic extract from the $C$. lineatifolia leaves, in addition to gastroprotective activity and TNF inhibition. However, the extraction process used was long and consumed a large amount of solvent. Therefore, the objective of this study was to obtain a bioactive extract rich in phenolics, in an extractive method of simpler, faster, and lower-cost execution. The $C$. lineatifolia leaves were dried and crushed, and the extractions were carried out in different solvents/mixtures (ethanol, methanol, ethyl acetate, and water) under ultrasonic bath (UB), electromagnetic stirring, and continuous reflux extraction (R). The extraction efficiency was evaluated by the flavonoid major compound concentration in the extracts, in a method developed by ultra-high performance liquid chromatography (UHPLC). Injection and pattern matching tests, and UHPLC analyses coupled to ultraviolet spectrometry were conducted to identify catechin and quercitrin. It has been demonstrated that the ethanolic extraction by $\mathrm{R}$ and the mixture of ethanol: water (8:2) by UB represented optimized methods in obtaining the flavonoid compounds identified. Thus, the results may contribute to chemical-biological extract standardization for gastric antiulcer activity evaluation. Key words: Campomanesia lineatifolia, extraction, flavonoids, optimization, UHPLC.

\section{Resumo}

Campomanesia lineatifolia Ruiz \& Pavón (gabiroba) é uma espécie nativa comestível encontrada na Floresta Tropical Amazônica. Estudos prévios têm demonstrado a natureza flavonoídica do extrato etanólico das folhas de C. lineatifolia, além de atividade gastroprotetora e inibição do TNF. No entanto, o processo de extração utilizado foi longo e consumiu uma grande quantidade de solvente. Portanto, o objetivo deste estudo foi obter um extrato bioativo rico em fenólicos, através de um método extrativo simples, rápido e de baixo custo de execução. As folhas de C. lineatifolia foram secas e trituradas e as extrações conduzidas em diferentes solventes / misturas (etanol, metanol, acetato de etila e água) sob banho ultrassônico, agitação eletromagnética e sistema contínuo de refluxo. A eficiência da extração foi avaliada pela concentração do componente flavonoídico majoritário nos extratos, em um método desenvolvido por cromatografia líquida de ultra eficiência. Ensaios de injeção e coinjeção com padrões autênticos, análises em cromatografia líquida de ultra eficiência acoplada à espectrometria ultravioleta foram conduzidos para identificar a presença de catequina e quercitrina. Demonstrou-se que a extração etanólica sob sistema contínuo de refluxo e a mistura de etanol:água (8:2) sob banho ultrassônico representaram métodos otimizados na obtenção dos componentes flavonoídicos identificados. Assim, os resultados obtidos podem contribuir para a padronização químicobiológica do extrato para a avaliação da atividade antiúlcera gástrica.

Palavras-chave: Campomanesia lineatifolia, extração, flavonoides, otimização, UHPLC
\end{abstract}

See supplementary material at <https://doi.org/10.6084/m9.figshare.12252368.v1>

\footnotetext{
${ }^{1}$ Universidade Federal de Minas Gerais, Depto. Produtos Naturais, Lab. Farmacognosia, Av. Presidente Antônio Carlos 6627, Campus Pampulha, 31270-901, Belo Horizonte, MG, Brasil.

${ }^{2}$ Faculdade Santa Rita, Depto. Farmácia e Biomedicina, C.P. 26, Estr. Real km 02, MG-129, 36400-000, Conselheiro Lafaiete, MG, Brasil.

3 ORCID: <https://orcid.org/0000-0001-6565-7925>

${ }^{4}$ Author for correspondence: niveacvn@gmail.com
} 


\section{Introduction}

Campomanesia lineatifolia Ruiz \& Pavón (Myrtaceae) originates from the western region of Amazonia and its geographic distribution comprises Amazonas (Brazilian state), eastern Colombia and Peru, and part of Amazonian Bolivia as well as non-flooded regions with hot and humid climate and clayey soils slightly drained, and may also be found in the inter-Andean valleys. It is a tree species that can reach 8 to 10 meters in height (D'eeckenbrugge \& Ferla 2000).

It is known by several common names, such as "gabiroba, gaviroba, champa, palillo, guayaba de leche or guayaba de mono". The name "gabiroba", in Guarani, means "tree with acid bark." The fruits are edible and much appreciated, widely used to make sweets, juices, and liqueurs (Villachica et al. 1996; D’eeckenbrugge \& Ferla 2000).

Barbosa (2009) revealed the flavonoid nature of the chemical constituents in the ethanolic extract of $C$. lineatifolia leaves obtained by percolation. This extract was subsequently subjected to successive partitions with hexane, dichloromethane, ethyl acetate, and n-butanol, obtaining flavonoid-enriched fractions with the ethyl acetate solvent. The extracts and fractions obtained showed a high content of phenols, such as flavonoids and tannins, in addition to high antioxidant activity, suggesting their ethnopharmacological relevance for antidiarrheal, gastric antiulcer, and cicatrizant activity. Also in this study, two substances were isolated and identified by spectroscopic techniques, catechin (tannin monomer) and quercitrin (flavonol). The same ethanolic extract and the ethyl acetate fraction of $C$. lineatifolia protected the gastric mucosa of rats against gastric lesions induced by ethanol and indomethacin (Madalosso et al. 2012). In a study of Brazilian medicinal plants in lipopolysaccharide(LPS-) stimulated THP-1 cells, Henriques et al. (2016) demonstrated the in vitro tumor necrosis factor (TNF) inhibitory activity of $C$. lineatifolia. It is important to emphasize that, in order to obtain extracts and fractions, the extractive method was long (over 48 hours) and involved the consumption of a large amount of solvents (approximately $2 \mathrm{~L}$ ) (Madalosso et al. 2012; Barbosa 2009). Therefore, the objective of this study was to optimize the extraction of phenolic-rich $C$. lineatifolia leaf extracts, developing simpler, faster, and less costly extraction planning with respect to the amount of solvents and/or solvent mixtures used in the process.

\section{Material and Methods}

\section{Plant material}

Campomanesia lineatifolia leaves were collected in February 2017, in the state of Minas Gerais, Brazil (1952'9.87'S, 4358'12.04”W). The species was identified by Dr. Marcos Sobral from the Botany Department of Instituto de Ciências Biológicas at Universidade Federal de Minas Gerais (UFMG), Belo Horizonte. A voucher specimen (no. BHCB 150.606) was deposited at the UFMG Herbarium. The registration in the National System of Genetic Heritage and Associated Traditional Knowledge Management (SisGen) was carried out and has the code A216C7C.

\section{Extraction}

The Campomanesia lineatifolia leaves were dried at $40{ }^{\circ} \mathrm{C} / 72 \mathrm{~h}$ with forced air circulation. The powdered dry leaves (particle size $0.5 \mathrm{~mm}$ ) were extracted by different methods in different solvents or mixtures thereof, as described in Table 1. All the tests were performed in triplicate.

$5.0 \mathrm{~g}$ of dried plant material was extracted using $100 \mathrm{~mL}$ of ethanol $96^{\circ}(\mathrm{EtOH})$ or extractive solvent mixtures (EtOH: $\mathrm{H}_{2} \mathrm{O} 8: 2$, v/v and EtOH: EtOAc $1: 1, \mathrm{v} / \mathrm{v})$ by liquid-solid maceration under ultrasonic bath at $27^{\circ} \mathrm{C} \pm 4{ }^{\circ} \mathrm{C}$ for $20 \mathrm{~min}$ (Ultronique, model Q1.8/40A). The supernatant was centrifuged at 1,400 g (Edutec Centrifuge, model EEQ-9004/B) for $5 \mathrm{~min}$ and then filtered. Evaporation of the solvent under vacuum was made in a rotary evaporator $\left(\mathrm{T}=60{ }^{\circ} \mathrm{C}\right.$ ) (Buchi rotary evaporator, model R-114 and waterbath B-480) or lyophilized (Liotop Liophilizer, model L101) in order to obtain the dry crude extracts.

In the liquid-solid maceration under electromagnetic stirring and in the continuous reflux extraction system, the same extraction conditions, vegetal material proportion, and solvent extractor type were used. In the first method, the material was subjected to extraction by maceration under electromagnetic stirring on a hot plate at $45-55^{\circ} \mathrm{C}$. In the second method, the solution was subjected to reflux method (ball capacitor) under heating $\left(\mathrm{T}=100 \pm 5{ }^{\circ} \mathrm{C}\right.$ ) for 3 cycles of $20 \mathrm{~min}$. The solutions were centrifuged, filtered, and dried in a rotary evaporator and lyophilizer, as described.

Chromatographic analysis by UHPLC

In order to evaluate the efficiency of the extractive method as a function of solvents and extractive solvent mixtures, the flavonoid main 
Table 1 - Experimental planning for evaluation of different extractive methods and solvents/solvent mixture, in the extraction of enriched extracts in phenolics from Campomanesia lineatifolia leaves.

\begin{tabular}{lll}
\hline Test & Solvents $/$ Solvent Mixture & Agitation $/$ Temperature $\left({ }^{\circ} \mathrm{C}\right)$ \\
\hline 1 & EtOH & Ultrasonic bath $(\mathrm{UB}) / 27{ }^{\circ} \mathrm{C} \pm 4{ }^{\circ} \mathrm{C}$ \\
2 & EtOH & Electromagnetic stirring $(\mathrm{ES}) / 50 \pm 2{ }^{\circ} \mathrm{C}$ \\
3 & EtOH & Continuous reflux extraction $(\mathrm{R}) / 100 \pm 5{ }^{\circ} \mathrm{C}$ \\
4 & EtOH: $\mathrm{H}_{2} \mathrm{O}(8: 2)$ & Ultrasonic bath $(\mathrm{UB}) / 27{ }^{\circ} \mathrm{C} \pm 4{ }^{\circ} \mathrm{C}$ \\
5 & EtOH: $\mathrm{H}_{2} \mathrm{O}(8: 2)$ & Electromagnetic stirring $(\mathrm{ES}) / 50 \pm 2{ }^{\circ} \mathrm{C}$ \\
6 & EtOH: $\mathrm{H}_{2} \mathrm{O}(8: 2)$ & Continuous reflux extraction $(\mathrm{R}) / 100 \pm 5{ }^{\circ} \mathrm{C}$ \\
7 & EtOH:AcOEt $(1: 1)$ & Ultrasonic bath $(\mathrm{UB}) / 27{ }^{\circ} \mathrm{C} \pm 4{ }^{\circ} \mathrm{C}$ \\
8 & EtOH:AcOEt $(1: 1)$ & Electromagnetic stirring $(\mathrm{ES}) / 50 \pm 2{ }^{\circ} \mathrm{C}$ \\
9 & EtOH:AcOEt $(1: 1)$ & Continuous reflux extraction $(\mathrm{R}) / 100 \pm 5{ }^{\circ} \mathrm{C}$ \\
\hline
\end{tabular}

$\mathrm{EtOH}=$ ethanol $96^{\circ} ; \mathrm{H}_{2} \mathrm{O}=$ water; $\mathrm{AcOEt}=$ ethyl acetate; $\mathrm{UB}=$ liquid-solid maceration under ultrasonic bath; ES = liquid-solid maceration under electromagnetic stirring; $\mathrm{R}=$ continuous reflux extraction.

compound concentrations in the extracts were analyzed by UHPLC-UV-DAD. The extract solutions obtained from $C$. lineatifolia vegetal drug were prepared in $5 \mathrm{mg} / \mathrm{mL}$ concentration, as described next. $5.0 \mathrm{mg}$ of the extracts were weighed into plastic microtubes and $1.0 \mathrm{~mL}$ of methanol analytical grade (Dinâmica - Química Contemporânea Ltda) was added. Dissolution was performed under ultrasonic bath for $20 \mathrm{~min}$. Then, the solutions were centrifuged at $10,000 \mathrm{~g}$ for 10 min (Cientec Centrifuge, model CT-5000R). The supernatant was filtrated through a Millex (Millipore, Bedford, MA, USA) LCR (pore size, $0.45 \mathrm{~lm}$ ) polytetrafluoroethylene membrane and transferred into $2.0 \mathrm{ml}$ vials.

Analyses were performed on a Waters UPLC Acquity System ${ }^{\circledR}$ (Milford, MA, USA) equipped with a quaternary pump, autosampler, photodiode array detector, and Empower software for data processing. An Acquity UPLC ${ }^{\circledR}$ BEH C18 column $(100 \times 2.1 \mathrm{~mm} \cdot 1.7 \mu \mathrm{m}$ i.d. $)$, and pre-column VanGuard Тм $\mathrm{C} 18(2.1 \times 5 \mathrm{~mm} \cdot 1.7 \mu \mathrm{m}$ i.d. $)$ was used at a temperature of $40^{\circ} \mathrm{C}$, flow rate of mobile phase $0.3 \mathrm{~mL} / \mathrm{min}$, and injection volume $2.0 \mu \mathrm{L}$. Ultraviolet (UV)-photodiode array detection was performed at $\lambda 270 \mathrm{~nm}$. UV spectra from $\lambda$ 200 to $600 \mathrm{~nm}$ were recorded on-line for peak identification. Mobile phase consisted of two solvents: (A) $0.1 \%$ formic acid in ultrapure water (Millipore Direct-Q Water Purifier), and (B) $0.1 \%$ formic acid in acetonitrile (LS Chemicals), and the following gradient program was performed: 0 $\min , 95 \% \mathrm{~A}-5 \% \mathrm{~B} ; 1 \mathrm{~min}, 92 \% \mathrm{~A}-8 \% \mathrm{~B} ; 22 \mathrm{~min}$, $78 \%$ A-22\% B; 25 min, 5\% A-95\% B; 27 min, $5 \% \mathrm{~A}-95 \% \mathrm{~B} ; 30 \mathrm{~min}, 95 \% \mathrm{~A}-5 \% \mathrm{~B}$.

Identification of major flavonoid compounds by UHPLC-UV-DAD and injection and coinjection assays with authentic standards.

The catechin and quercitrin ( $\geq 98 \%$, Sigma Aldrich) standards were individually injected into UHPLC-UV-DAD, and prepared in analyticalgrade methanol at a concentration of $1.0 \mathrm{mg} /$ $\mathrm{mL}$, as described below. $1.0 \mathrm{mg}$ of the standards were weighed in plastic microtubes and $1.0 \mathrm{~mL}$ of analytical-grade methanol was added. Dissolution was performed under ultrasonic bath for $20 \mathrm{~min}$. Then, the solutions were centrifuged at $10,000 \mathrm{~g}$ for $10 \mathrm{~min}$ and the supernatant was transferred to vials. The chromatographic profiles obtained from the standards were compared to that of the EtOH R extract, as a function of their UV spectra obtained online and respective retention times.

Coinjection assays were performed by UHPLC-UV-DAD. A solution of $5.0 \mathrm{mg} / \mathrm{mL}$ EtOH extract (prepared as described in the section "Chromatographic analysis") fortified with $100 \mu \mathrm{L}$ of standard quercitrin solution $(1.0 \mathrm{mg} / \mathrm{mL})$ was analyzed. Chromatographic conditions described previously were employed. The injection volume was $2.0 \mu \mathrm{L}$, and the extract solubilization was made in analytical-grade methanol. 
Statistical analysis

Statistical analyses were performed using the Graph Prism version 6.0 program. All results were expressed as mean \pm standard error values. For the comparison of more than two groups and the relationships of independent factors, One-way ANOVA or Two-way ANOVA tests were used, respectively, followed by Tukey's post-test for multiple comparisons of small samples. The choice of these tests was performed according to the data relative to descriptive statistics and $\mathrm{p}<0.05$ was considered significant.

\section{Results and Discussion}

Flavonoids are found in plants, especially in their glycosylated form, being the most common sugars $O$-glycosylated, and $C$-glycosylated, D-glucose, and L-rhamnosis (Hermann 1988; Erlund 2004). The effect of glycosylation makes the flavonoids have a greater solubility in water and, therefore, aqueous and hydroalcoholic solutions can be considered more suitable for the extraction of these compounds. Less polar flavonoid aglycones, such as isoflavones, flavanones, flavones, and flavonols, can be extracted using low to medium polar solvents such as chloroform, dichloromethane, ethyl ether, or ethyl acetate (Andersen \& Markham 2006).

For a preliminary analysis to obtain enriched flavonoid extracts, different solvents (ethanol, methanol, ethyl acetate, and water) and solvent mixtures (ethanol: water in the proportions $8: 2$, $7: 3,1: 1,3: 7,2: 8, \mathrm{v} / \mathrm{v})$, as well as liquid-liquid (dichloromethane followed by ethyl acetate) and solid-liquid (ethyl acetate) partitions of C. lineatifolia, were evaluated by HPLC. The results showed that EtOH and EtOH: $\mathrm{H}_{2} \mathrm{O}$ extracts $(8: 2$ and $7: 3, \mathrm{v} / \mathrm{v})$ obtained by ultrasonic bath maceration, and the ethyl acetate fraction defatted with dichloromethane followed by ethyl acetate obtained by liquid-liquid partition presented efficiency in extracting phenolic compounds, previously identified by Barbosa (2009), catechin and quercitrin (supplementary material, available at $<$ https://doi.org/10.6084/m9.figshare. 12252368 . v1). It is important to note that although the preliminary tests demonstrated the efficiency described by the US extraction method, no solvent or solvent mixture was able to optimize the obtainment of all selected flavonoid compounds to evaluate the extraction efficiency. Even though the ethyl acetate fraction showed efficiency in the extraction of these substances, the method used in the partition was long and laborious, and with higher consumption of solvents, approximately 2 L (Barbosa 2009).

The EtOH solvent and EtOH: $\mathrm{H}_{2} \mathrm{O}(8: 2)$ solvent mixture were maintained for the new extractive methods proposed in the experimental design (Tab. 1), in view of the efficiency demonstrated in obtaining rich extracts in phenolics (previously evaluated by HPLC and UHPLC), as well as good solubility of the phenolic compounds in these solvents (Daneshfar et al. 2008; Barbosa 2009; Vuong et al. 2011; Madalosso et al. 2012; Cuevas-Valenzuela et al. 2014). As there was no statistical difference between the EtOH: $\mathrm{H}_{2} \mathrm{O}(8: 2)$ and $(7: 3)$ mixtures, the latter was not included in the planning, since it is more difficult to remove the water that is in the highest proportion in this extract. In addition, a new solvent mixture was included in the planning, ethanol:ethyl acetate (1:1) [EtOH:EtOAc (1:1)], considering that the ethyl acetate solvent has demonstrated efficiency in phenolic compound extraction, as well as the fact that the ethyl acetate fraction has shown a good result (Barbosa 2009; Daneshfar et al. 2008; Vuong et al. 2011; Ferreira et al. 2013).

The extractive methods included in this study were selected to develop sustainable strategies to use less labor intensive, less solvent, as well as the use of safer solvents (which include ethanol) than that previously used by our research group (Barbosa 2009). The inclusion of ethyl acetate solvent is due to the fact that ethyl acetate fraction presented gastroprotective activity in models in vivo, also tested by our research group (Barbosa 2009; Madalosso et al. 2012; Machado et al. 2017). These in vivo assays will be conducted with the optimized extract.

According to the literature, several extractive methods have been proposed to obtain enriched phenolic extracts. Machado et al. (2017) developed and optimized an extractive method to obtain good yields of phenolic compounds in guaraná extracts, employed liquid-solid maceration using a solvent mixture of ethanol: water $(8: 2, \mathrm{v} / \mathrm{v})$ with diluted acid $\left(\mathrm{H}_{3} \mathrm{PO}_{4} 0.1 \%\right.$ in water, $\left.\mathrm{v} / \mathrm{v}\right)$ under electromagnetic stirring, temperature between $75-78{ }^{\circ} \mathrm{C}$, three successive extractions in $10 \mathrm{~min}$ each. Other studies have focused on the phenolic compound extraction using solvents that are accepted by the pharmaceutical and food industries, e.g. water and ethanol, in combination with assisted extraction techniques such as pressurized liquid 
extraction, microwave extraction, and extraction by ultrasound (Duba et al. 2015; Xu et al. 2015; Bodoira et al. 2017a, b; Caleja et al. 2017), besides the high temperatures used to improve the phenolic constituent solubility of the extract, increasing the extractive process efficiency (Daneshfar et al. 2008; Srinivas et al. 2010; Cuevas-Valenzuela et al. 2014; Bodoira et al. 2019).

To analyze the results of different extractive methods and solvents or solvent mixtures used,
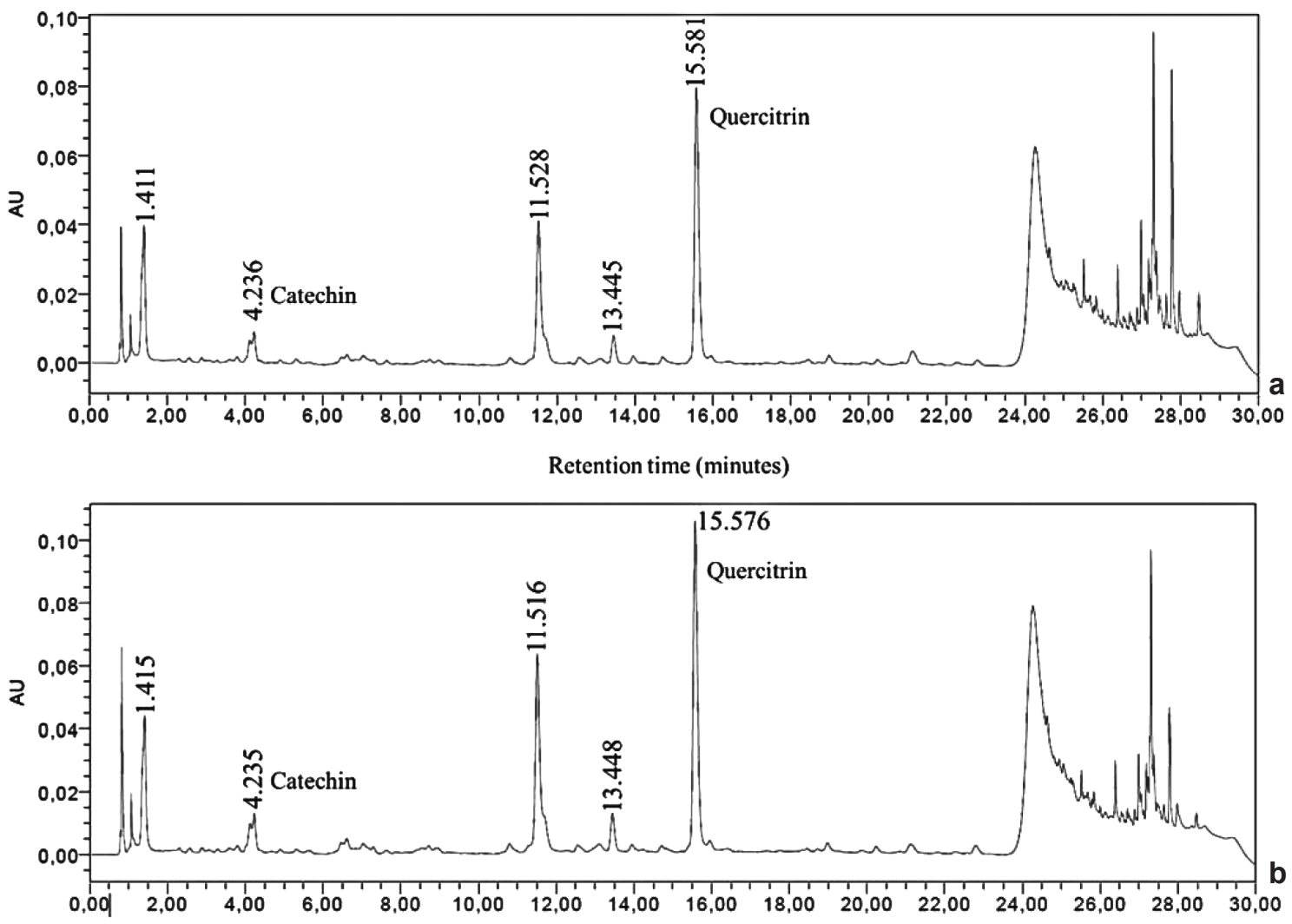

Retention time (minutes)

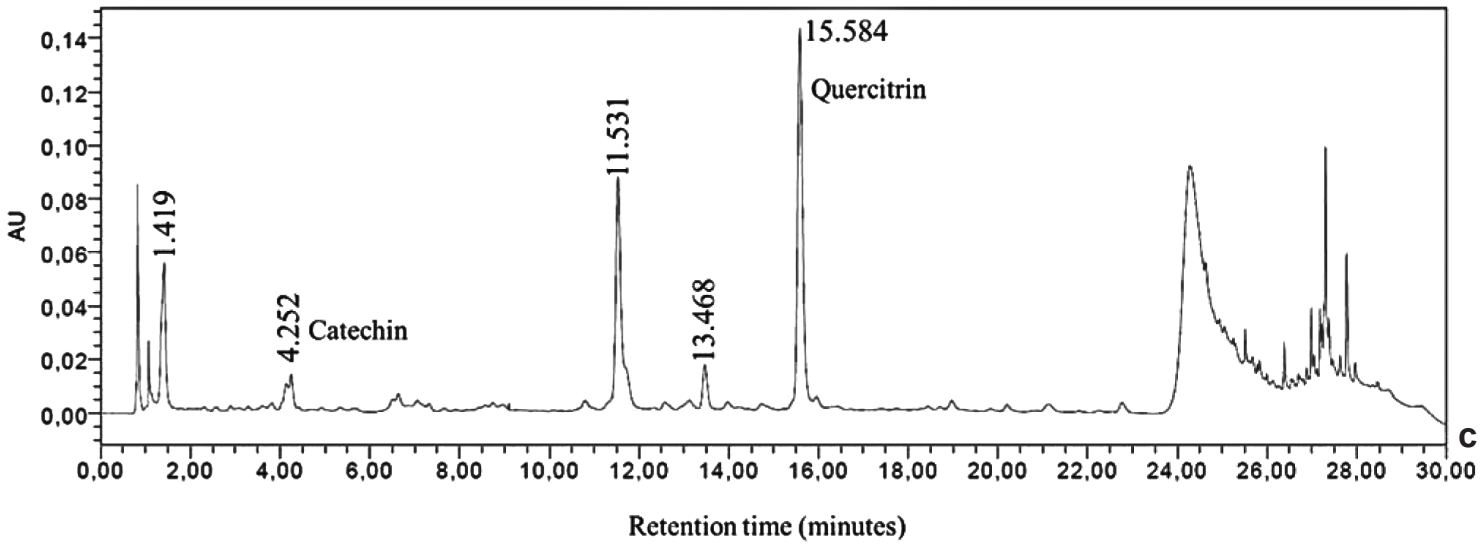

Figure 1 - a-c. Chromatographic profile obtained by UHPLC-UV-DAD, in $\lambda=270 \mathrm{~nm}$, for EtOH C. lineatifolia extract, in different extractive methods - a. extract EtOH UB; b. extract EtOH ES; c. extract EtOH R. Legend: UHPLC$\mathrm{UV}-\mathrm{DAD}=$ ultra-high performance liquid chromatography coupled to ultraviolet-photodiode array detector; EtOH $=$ ethanol; $\mathrm{UB}=$ maceration under ultrasonic bath; $\mathrm{ES}=$ maceration under electromagnetic stirring; $\mathrm{R}=$ extraction in continuous reflux system. 
chromatographic profiles were obtained. In these chromatograms, five substances with a flavonoid profile, called peaks 1 to 5 (Fig. 1), were selected.

It was demonstrated, from the chromatogram (Fig. 1), that the five selected peaks presented close retention times for all extracts of 1.4 (peak 1), 4.2 (peak 2), 11.5 (peak 3), 13.4 (peak 4), and 15.5 (peak 5) minutes. The UV spectra obtained on-line for these peaks indicated absorption at two similar wavelengths, around $250-280 \mathrm{~nm}$ and $340-350 \mathrm{~nm}$, compatible with the Bands II and I characteristics of flavonoids respectively (Mabry et al. 1970). The 2 (peak 2) and 5 (peak 5) compounds showed the same wavelength absorption of Bands II and I, compared to the spectra obtained by Barbosa (2009), catechin and quercitrin, respectively. Injection assays of the catechin standard, and injection and coinjection of the quercitrin standard confirmed the presence of these compounds in $C$. lineatifolia leaf extracts.

The respective peak areas were compared for the different solvent/solvent mixture and extractive methods tested. When analyzing the relationship between solvent variables and solvent mixtures, no statistical difference was observed in the extractive profile between peaks 1, 2, and 4 (Fig. 2). Peaks 3 and 5 have already shown statistical difference in different extraction solvents and methods.

For the extraction of compound 3 (peak 3 ), the reflux method using ethanol (EtOH R) was statistically different from the UB EtOH systems; EtOH ES; EtOH:EtOAc (1:1) UB, R, and ES, but without statistical difference when EtOH: $\mathrm{H}_{2} \mathrm{O}$ solvents (8:2) were used for all methods (Fig. 3a).
For the extraction of compound 5 (peak 5), the maceration UB method using solvent mixture EtOH: $\mathrm{H}_{2} \mathrm{O}(8: 2)$ was statistically different in relation to the EtOH: $\mathrm{H}_{2} \mathrm{O}$ systems (8:2) ES and R; EtOH UB and ES; and EtOH:EtOAc (1:1) UB, $\mathrm{ES}$, and $\mathrm{R}$, but without statistical difference when the solvent ethanol was used, in the reflux system (EtOH R), according to Figure 3b.

Thus, extractions by EtOH R and EtOH: $\mathrm{H}_{2} \mathrm{O}$ (8:2) UB represented optimized methods to obtain the selected major flavonoid compounds, peaks of 1 to 5 in $C$. lineatifolia leaves. The extractive methods then optimized by the solidliquid extraction technique represent an extraction commonly used in vegetal materials, using liquid solvents, due to their wide applicability, efficiency, and ease of use (Sharma \& Gupta 2015; Safdar et al. 2017). In general, the technique involves the drying and milling of plant material and the choice of a solvent and a suitable procedure for the compounds of interest extraction (Sharma \& Gupta 2015), including here the optimized techniques observed, ultrasonic bath maceration and continuous reflux system. Albu et al. (2004) used ultrasound to extract phenolic compounds from rosemary and demonstrated that the operating time was decreased using this extractive method. The thermal effects of ultrasound occur when ultrasonic waves are converted to heat and absorbed by the plant tissue, while the mechanical effects cause acoustic cavitation, causing a bubble to grow resulting in cellular rupture, with consequent improvement of the solvent penetration in plant material and intracellular content release by cell wall rupture. In

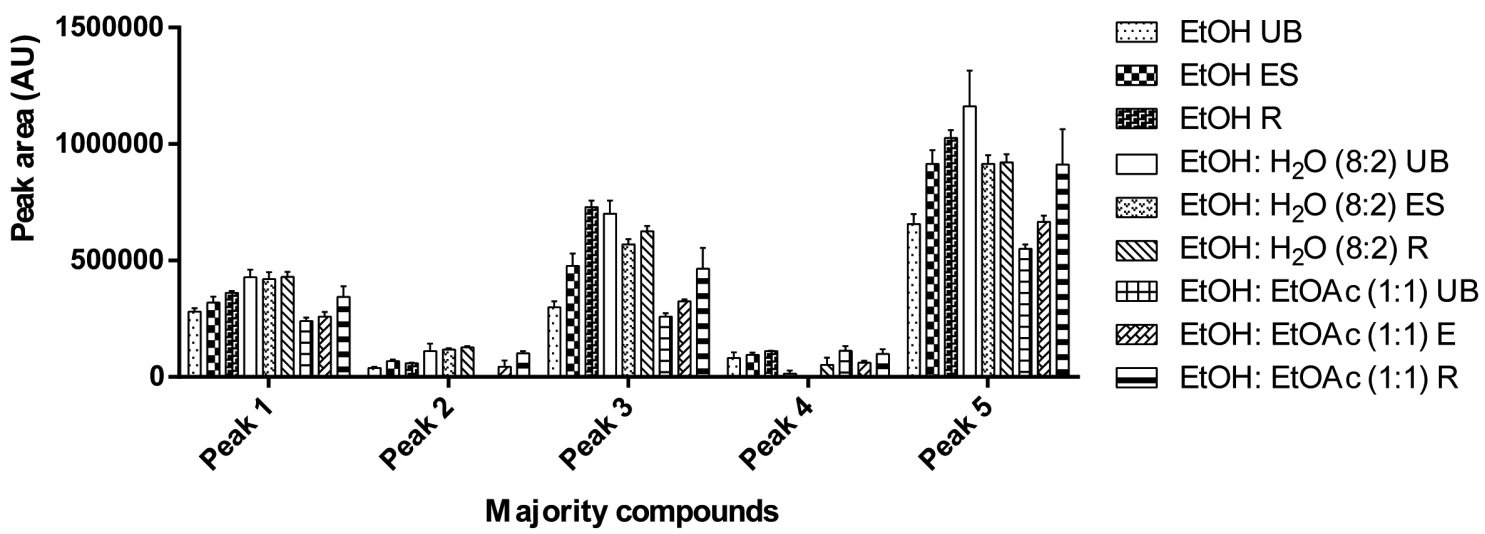

Figure 2 - Peak areas of the major compounds (peaks 1 to 5) of $C$. lineatifolia extracts obtained by UHPLC-UV-DAD in different extractive methods and solvents. Each bar represents the mean \pm SEM, Two-way ANOVA, with Tukey's post-test comparison $(\mathrm{n}=3), p<0.05$. Legend: $\mathrm{EtOH}=$ ethanol; $\mathrm{H}_{2} \mathrm{O}=$ water; EtOAc $=$ ethyl acetate; $\mathrm{UB}=$ maceration under ultrasonic bath; $\mathrm{ES}=$ maceration under electromagnetic stirring; $\mathrm{R}=$ extraction in continuous reflux system. 
addition, the bioactive compound extraction under ultrasonic irradiation offers high reproducibility in short periods of time, simplified handling, reduced solvent consumption, use of lower temperatures, and lower energy consumption (Khan et al. 2010).

In the reflux extraction technique, a higher temperature $\left(100 \pm 5^{\circ} \mathrm{C}\right)$ was used in a continuous maceration extraction system to allow solvent reflux. The temperature of the extractive process is another parameter that must be taken into account, since the continuous reflux system was presented as an efficient method in the extraction with pure solvent. Several studies have shown that increasing temperatures improve the solubility of the phenolic compounds in extractive solvents and optimizes the extraction of these compounds from plant raw materials (Daneshfar et al. 2008; Srinivas et al. 2010; Cuevas-Valenzuela et al. 2014; Bodoira et al. 2019), which may justify the results obtained in this study.

Organic polar solvents, such as ethanol, and hydroalcoholic mixtures are cheaper options and have lower toxicity, as well as a large capacity for dissolution and extraction of various plant constituents (Xu et al. 2017). In addition, it is important to highlight that safer solvents (here included water and ethanol) are being prioritized in routine laboratory analyses to establish the chromatographic fingerprints of numerous plant samples. This approach is particularly useful for the medicinal plant analysis due to the program created by the Brazil's Ministry of Health to enable the use of herbal medicines by the Brazilian Unified National Health System (SUS) (Brasil 2009; Funari et al. 2014) and to comply with the National Sanitary Vigilance Agency (ANVISA) regulations for the safe use of herbal medicines.

\section{Conclusions}

Our results demonstrated the influence of isolated polar solvents $(\mathrm{EtOH})$ and hydroalcoholic mixture (EtOH: $\mathrm{H}_{2} \mathrm{O}$ 8:2, v/v) on the flavonoid extraction, relating the solubility profile of these compounds in polar solvents. The extractive methods by maceration under ultrasonic bath and by continuous reflux system proved to be effective methods to obtain C. lineatifolia flavonoidenriched extracts. Injection and coinjection assays with authentic standards allowed confirming the presence of catechin (flavan-3-ol) and quercitrin (flavonol), which may contribute to the chemicalbiological validation of $C$. lineatifolia leaf ethanolic extract, in relation to its gastric antiulcer activity.
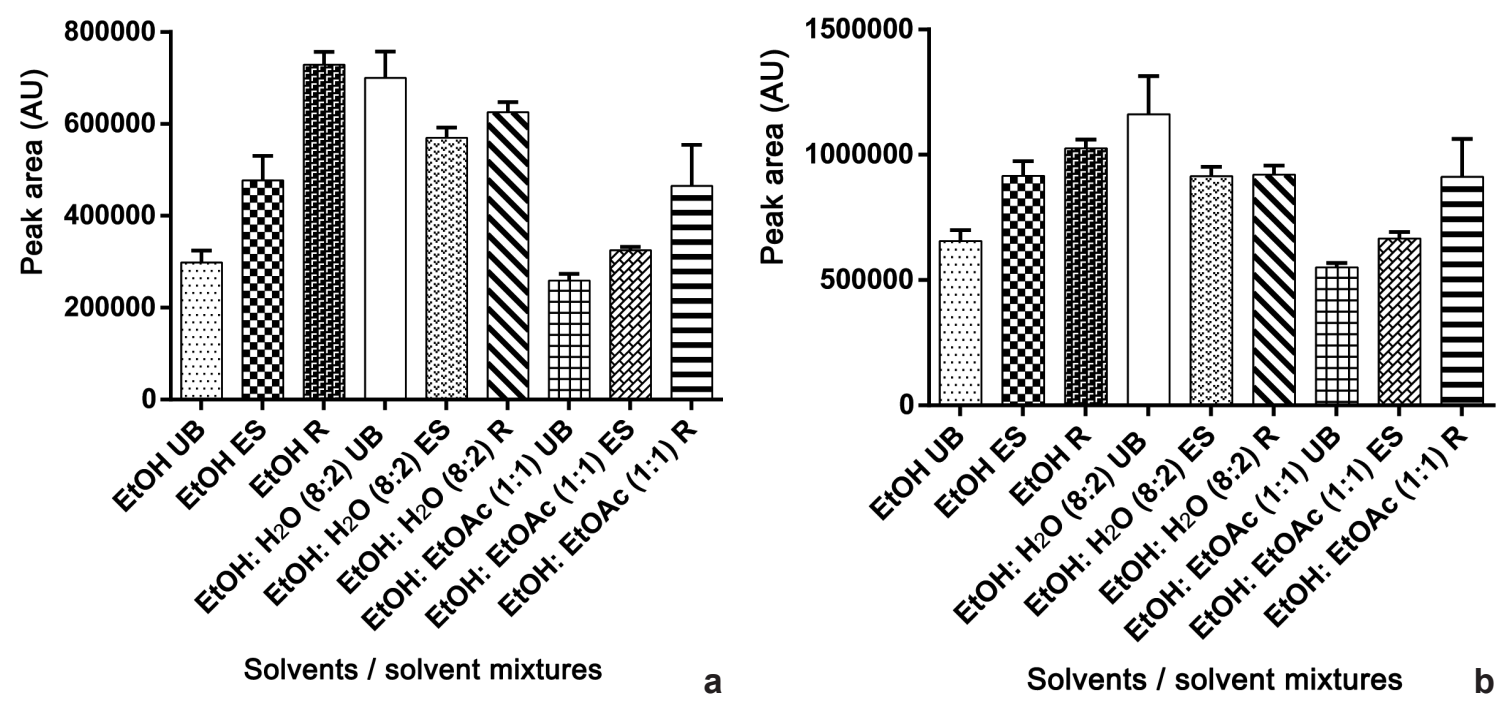

Figure 3 - Evaluation of extractive methods of $C$. lineatifolia extracts, according to chromatogram area obtained by UHPLC-UV-DAD, for compound 3 (a) e 5 (b). Legend: EtOH = ethanol; $\mathrm{H} 2 \mathrm{O}=$ water; EtOAc = ethyl acetate; $\mathrm{UB}=$ maceration under ultrasonic bath; $\mathrm{ES}=$ maceration under electromagnetic stirring; $\mathrm{R}=$ extraction in continuous reflux system. Test: Two-way ANOVA, followed by Tukey's post-test $(n=3)$. Each bar represents the mean \pm SEM, and a, $b$, $\mathrm{c}$ represent means that differ from each other $(\mathrm{p}<0.05)$. 
In current times, where there is a growing concern about developing sustainable strategies, the use of less labor intensive, less solvent extraction methods, as well as the use of safer solvents, has become a practical and sustainable choice for driving future studies to evaluate the biological activity of $C$. lineatifolia extracts.

\section{Acknowledgments}

Fundação de Amparo a Pesquisa do Estado de Minas Gerais (FAPEMIG), Conselho Nacional de Desenvolvimento Científico e Tecnológico (CNPq), Coordenação de Aperfeiçoamento de Pessoal de Nível Superior (CAPES) and PRPq of Universidade Federal de Minas Geral are acknowledged for financial or fellowship support. We also thank the technicians and researchers of Laboratório de Farmacognosia e Homeopatia da Faculdade de Farmácia, Universidade Federal de Minas Gerais for their collaboration in conducting the studies.

\section{References}

Albu S, Joyce E, Paniwnyk L, Loirmer J \& Mason T (2004) Potential use of ultrasound in the extraction of antioxidants from Rosmarinus officinalis for the food and pharmaceutical industry. Ultrasonics Sonochemistry 11: 261-265.

Andersen ØM \& Markham KR (2006) Flavonoids: chemistry, biochemistry and applications. In: Marston A \& Hostettmann K (eds.) Separation and quantification of flavonoids. CRC Taylor \& Francis, Boca Raton. Pp. 1-3.

Barbosa J (2009) Campomanesia lineatifolia Ruiz e Pav.: estudo fitoquímico e avaliação da atividade antioxidante. Dissertação de Mestrado. Universidade Federal de Minas Gerais, Belo Horizonte. 113p.

Bodoira R, Velez A, Andreatta AE, Martínez M \& Maestri D (2017a) Extraction of bioactive compounds from sesame (Sesamum indicum L.) defatted seeds using water and ethanol under sub-critical conditions. Food Chemistry 237: 114-120.

Bodoira R, Rossi Y, Montenegro M, Maestri D \& Velez A (2017b) Extraction of antioxidant polyphenolic compounds from peanut skin using water-ethanol at high pressure and temperature conditions. Journal of Supercritical Fluids 128: 57-65.

Bodoira R, Velez A, Rovetto L, Ribotta P, Maestri D \& Martínez M (2019) Subcritical fluid extraction of antioxidant phenolic compounds from Pistachio (Pistacia vera L.) Nuts: experiments, modeling, and optimization. Journal of Food Science $0: 1-8$.

Brasil (2009) Programa Nacional de Plantas Medicinais e Fitoterápicos / Ministério da Saúde, Secretaria de Ciência, Tecnologia e Insumos Estratégicos, Departamento de Assistência Farmacêutica e
Insumos Estratégicos. In: Nascimento Junior JM, Torres KR \& Alves RMS (eds.) Diretrizes, subdiretrizes, ações, gestores, envolvidos, prazos e recursos. Ministério da Saúde, Brasília. Pp. 42-60.

Caleja C, Barros L, Prieto MA, Barreiro Oliveira MF \& Ferreira ICFR (2017) Extraction of rosmarinic acid from Melissa officinalis L. by heat-, microwave- and ultrasound-assisted extraction techniques: A comparative study through response surface analysis. Separation and Purification Technology 186: 297-308.

Cuevas-Valenzuela J, González-Rojas A, Wisniak J, Apelblat A \& Pérez-Correa JR (2014) Solubility of $(+)$-catechin in water and water-ethanol mixtures within the temperature range 277.6-331.2 K: fundamental data to design polyphenol extraction processes. Fluid Phase Equilibria 382: 279-285.

D'Eeckenbrugge GC \& Ferla DL (2000) Fruits from America: an ethonobotanical inventory. Available at $<$ http://ciatweb.ciat.cgiar.org/ ipgri/fruits_from_americas/frutales/Ficha $\% 20$ Campomanesia\%20lineatifolia.htm>. Access on 10 May 2019.

Daneshfar A, Ghaziaskar HS \& Homayoun N (2008) Solubility of gallic acid in methanol, ethanol, water, and ethyl acetate. Journal of Chemical \& Engineering Data 53: 776-778.

Duba KS, Casazza AA, Mohamed HB, Perego P \& Fiori L (2015) Extraction of polyphenols from grape skins and defatted grape seeds using subcritical water: experiments and modeling. Food Bioproducts Processing 94: 29-38.

Erlund I (2004) Review of the flavonoids quercetin, hesperetin, and naringenin. Dietary sources, bioactivities, bioavailability, and epidemiology. Nutrition Research 24: 851-874.

Ferreira LC, Grabe-Guimarães A, Paula CA, Michel MC, Guimarães RG, Rezende AS, Souza Filho JD \& Saúde-Guimarães DA (2013) Anti-inflammatory and antinociceptive activities of Campomanesia adamantium. Journal of Ethnopharmacology 145: 100-108.

Funari CS, Carneiro RL, Andrade AM, Hilder EF \& Cavalheiro AJ (2014) Green chromatographic fingerprinting: an environmentally friendly approach for the development of separation methods for fingerprinting complex matrices. Journal of separation science 37: 37-44.

Henriques BO, Corrêa O, Azevedo EP, Pádua RM, Oliveira VL, Oliveira TH, Boff D, Dias AC, Souza DG, Amaral FA, Teixeira MM, Castilho RO \& Braga FC (2016) In vitro TNF- $\alpha$ inhibitory activity of Brazilian plants and anti-inflammatory effect of Stryphnodendron adstringens in an acute arthritis model. Evidence-Based Complementary and Alternative Medicine 2016: 9872598. 
Hermann K (1988) On the ocurrence of flavonol and flavone glycosides in vegetables. Zeitschrift für Lebensmittel-Untersuchung und Forschung 186: $1-5$.

Khan MK, Abert-Vian M, Fabiano-Tixier A, Dangles O \& Chemat F (2010) Ultrasound-assisted extraction of polyphenols (flavanone glycosides) from orange (Citrus sinensis L.) peel. Food chemistry 119: 851-858.

Machado KN, Freitas AAD, Cunha LH, Faraco AAG, Pádua RMD, Braga FC, Vianna-Soares CD \& Castilho RO (2017) A rapid simultaneous determination of methylxantines and proanthocyanidins in Brazilian guaraná (Paullinia cupana Kunth.). Food Chemistry 239: 180-188.

Madalosso RC, Oliveira GC, Martins MT, Vieira AE, Barbosa J, Caliari MV, Castilho RO \& Tagliati CA (2012) Campomanesia lineatifolia Ruiz \& Pav. as a gastroprotective agent. Journal of Ethnopharmacology 139: 772-779.

Mabry T, Markham KR \& Thomas MB (1970) The systematic identification of flavonoids. In: Mabry T, Markham KR \& Thomas MB (eds.) The ultraviolet spectra of flavones and flavonols. Springer-Verlag, New York. Pp. 41-57.

Safdar MN, Kausar T, Jabbar S, Mumtaz A, Ahad K \& Saddozai AA (2017) Extraction and quantification of polyphenols from kinnow (Citrus reticulate L.) peel using ultrasound and maceration techniques.
Journal of Food and Drug Analysis 25: 488-500. Sharma SS \& Gupta YK (2015) Drug development from natural resource: a systematic approach. MiniReviews in Medicinal Chemistry 15: 52-57.

Srinivas K, King JH, Howard LR \& Monrad JK (2010) Solubility of gallic acid, catechin, and protocatechuic acid in subcritical water from (298.75 to 415.85) K. Journal of Chemical \& Engineering Data 55: 3101-3108.

Villachica H, Carvalho JFU, Muller CH, Diaz CS \& Almanza, M (1996) Frutales y hortializas promisorios de la Amazonia. SPT-TCA No. 44. Tratado de Cooperacion Amozonica. Secretaria Pro-Tempore, Lima. Pp. 212-213.

Vuong QV, Stathopoulos CE, Nguyen MH, Golding JB \& Roach PD (2011) Isolation of green tea catechins and their utilization in the food industry. Food Reviews International 27: 227-247.

Xu H, Wang W, Liu X, Yuan F \& Gao Y (2015) Antioxidative phenolics obtained from spent coffee grounds (Coffea arabica L.) by subcritical water extraction. Industrial Crops and Products 76: 946-954.

Xu D, Zheng J, Zhou Y, Li Y, Li S \& Li H (2017) Ultrasound-assisted extraction of natural antioxidants from the flower of Limonium sinuatum: optimization and comparison with conventional methods. Food Chemistry 217: 552-559. 